\title{
THE SPECULATIVE CITY
}

\section{Emergent Forms and Norms of the Built Environment}

Edited by Cecilia L. Chu and Shenjing $\mathrm{He}$

The Speculative City explores property speculation as a key aspect of financialization and its role in reshaping the contemporary built environment. The book offers a series of case studies that encompass a range of cities whose urban fabrics have undergone significant transformation in recent years.

While the forms of these developments share many similarities, their trajectories and social outcomes were contingent upon existing planning and policy frameworks in addition to the historical roles assumed by the state and the private sector in housing and welfare provision. By paying close attention to the forces and actors involved in property development, this book underscores that the built environment has played an integral part in shaping new values and collective aspirations, while also facilitating the spread of financial logics in urban governance. The essays in this collection show that these dynamics represent a larger shift of politics and culture in the ongoing production of urban space and prompt reflections on future trajectories of finance-led property speculation.

CECILIA L. CHU is an associate professor in the Division of Landscape Architecture at The University of Hong Kong.

SHENJING HE is a professor and associate dean in the Faculty of Architecture at The University of Hong Kong. 
This page intentionally left blank 


\section{The Speculative City}

Emergent Forms and Norms of the Built Environment

EDITED BY CECILIA L. CHU AND SHENJING HE

UNIVERSITY OF TORONTO PRESS

Toronto Buffalo London 
(C) University of Toronto Press 2022

Toronto Buffalo London

utorontopress.com

Printed in the U.S.A.

ISBN 978-1-4875-0719-0 (cloth) ISBN 978-1-4875-3576-6 (EPUB)

ISBN 978-1-4875-2488-3 (paper) ISBN 978-1-4875-3575-9 (PDF)

\section{Library and Archives Canada Cataloguing in Publication}

Title: The speculative city : emergent forms and norms of the built

environment / edited by Cecilia L. Chu and Shenjing He.

Names: Chu, Cecilia L., editor. | He, Shenjing, editor.

Description: Includes bibliographical references and index.

Identifiers: Canadiana (print) 20210369116 | Canadiana (ebook) 20210369167 |

ISBN 9781487524883 (paper) | ISBN 9781487507190 (cloth) |

ISBN 9781487535766 (EPUB) | ISBN 9781487535759 (PDF)

Subjects: LCSH: Land speculation - Case studies. | LCSH: Urban renewal Case studies. | LCGFT: Case studies.

Classification: LCC HD111 .S64 2022 | DDC 333.73/13 - dc23

Every effort has been made to contact copyright holders; in the event of an error or omission, please contact the publisher.

We wish to acknowledge the land on which the University of Toronto Press operates. This land is the traditional territory of the Wendat, the Anishnaabeg, the Haudenosaunee, the Métis, and the Mississaugas of the Credit First Nation.

University of Toronto Press acknowledges the financial support of the Government of Canada, the Canada Council for the Arts, and the Ontario Arts Council, an agency of the Government of Ontario, for its publishing activities.
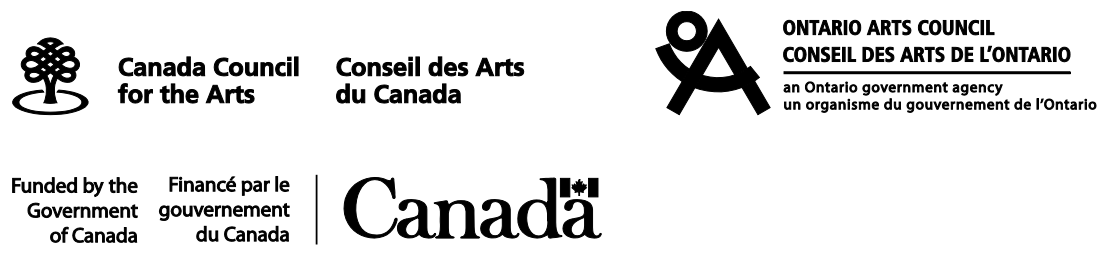